\title{
Science of Camel and Yak Milks: Human Nutrition and Health Perspectives
}

\begin{abstract}
Akbar Nikkhah
Department of Animal Sciences, University of Zanjan, Zanjan, Iran.

Email: nikkhah@znu.ac.ir

Received May $17^{\text {th }}, 2011$; revised July $26^{\text {th }}, 2011$; accepted August $4^{\text {th }}, 2011$.

ABSTRACT

Camels and yaks milks are rich in numerous bioactive substances that function beyond their nutritive value. Camel milk is more similar to goat milk and contains less short-chain fatty acids than cow, sheep and buffalo milks, and about 3 times greater vitamin-C than cow milk. One $\mathrm{kg}$ of camel milk meets $100 \%$ of daily human requirements for calcium and phosphorus, $57.6 \%$ for potassium, $40 \%$ for iron, copper, zinc and magnesium, and $24 \%$ for sodium. Camel milk helps treat liver problems, lowers bilirubin output, lightens vitamin inadequacy and nutrient deficiency, and boosts immunity. Camel milk reduces allergies caused by cow dairy products. Camel milk has low milk fat made mainly from polyunsaturated fatty acids. It lacks $\beta$-lactoglobulin and is rich in immunoglobulins, compatible with human milk. Yak milk has $16.9 \%-17.7 \%$ solids, $4.9 \%$ - 5.3\% protein, $5.5 \%$ - 7.2\% fat, $4.5 \%-5.0 \%$ lactose, and $0.8 \%-0.9 \%$ minerals. Yak milk fat is richer in polyunsaturated fatty acids, protein, casein and fat than cow milk. Yak milk casein is used to produce antihypertensive peptides with capacities for producing value-added functional foods and proteins. Continual systematic education of milk science especially for non-cow species will be an obligation for health implications to be optimally perceived by human populations worldwide.
\end{abstract}

Keywords: Camel, Education, Health, Immunity, Milk, Nutrition, Yak

\section{Introduction}

Asia, Europe and North America produce most of the world milk products (Figure 1) [1]. The most of milk produced is from cattle except for Asia where cattle and buffalo are the key milk producers (Figure 1). The science of non-cow milks has, however, not been broadly, scientifically, and systematically appreciated by the public. The greatest dairy food consumption occurs in Western Europe, Scandinavians, Australia, and Canada (Table 1). These highlight the inevitability of further education and research data dissemination in both above and other world regions on human health implications of milk, especially from non-cow species.

Milk secretion results from pregastric fermentation of plant cells that generate volatile fatty acids (VFA) and microbial mass $[2,3]$. As such, milk is considered the most natural and efficient functional food. Such a global nutritional fame is because milk is produced from most abundant, lease digestible matters in the nature (e.g., cellulose), and also because it encompasses numerous bioactives that function beyond their nutritive value. No food can replace milk for neonatal development of brain, nervous, immune, and skeletal systems, which is an evolutionary testimony for its irreplaceable roles in creation of upcoming higher quality generations [3]. Lactating women on milk secret breast milk enriched with $\beta$-lactoglobulin and ovalbumin [4]. Livestock milk may be enriched with vitamin-E for greater nutritional value [5]. Milk from immunized ruminants has reduced hypercholesterolemia [6]. Conjugated linoleic acid (CLA) of mainly CLA cis9, trans11 (75\% - 90\%) and CLA trans10, cis 12 have implications as anti-carcinogenic, anti-atherogenic, anti-inflammatory, and anti-lipogenic agents $[7,8]$. As such, ruminant research has attempted to manipulate nutritional programs to enrich milk with CLA [7]. Milk immunoglobulins act against Enterotoxigenic Escherichia coli [9]. Dairy consumption has also reduced metabolic syndromes [10]. Whey proteins are insulinotropic and medium chain fatty acids improve insulin action and fat metabolism. Medium and short chain fatty acids in milk specifically butyric acid, publically considered likely unhealthy, can improve intestinal fat and nitrogen assimilation and insulin sensitivity $[11,12]$. 


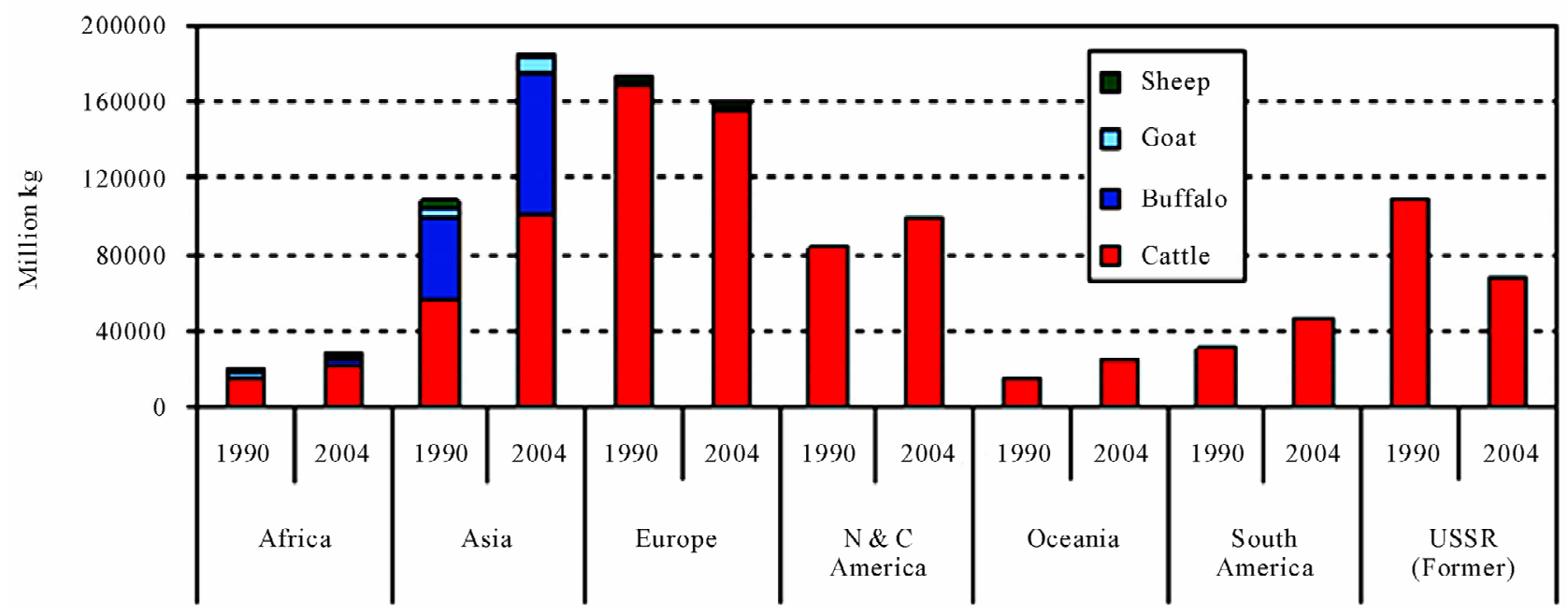

Figure 1. Total and proportional world ruminant milk production.

Table 1. Highest per capita dairy products consumers.

\begin{tabular}{lccc}
\hline Country & Milk, liters & Cheese, kg & Butter, kg \\
\hline Finland & 184 & 19.1 & 5.3 \\
Sweden & 146 & 18.5 & 1.0 \\
Ireland & 130 & 10.5 & 2.9 \\
Netherlands & 123 & 20.4 & 3.3 \\
Norway & 117 & 16.0 & 4.3 \\
Spain & 119 & 9.6 & 1.0 \\
Switzerland & 113 & 22.2 & 5.6 \\
Britain & 111 & 12.2 & 3.7 \\
Australia & 106 & 11.7 & 3.7 \\
Canada & 95 & 12.2 & 3.3 \\
\hline
\end{tabular}

Given the versatile raising environment, evolution, genetics, and feeding management, milk composition differs vastly among livestock (Table 2). Protein and calcium supplies from animal foods including dairy products vary considerably among countries. Average intake in many regions is well below minimum daily requirements of about $70 \mathrm{~g}$ protein and $800 \mathrm{mg}$ calcium [13]. Camel milk is produced very economically by animals living in the toughest environments. Camel milk is three times richer in vitamin $\mathrm{C}$ than cow milk. In some countries including Iran, Russia, Kazakhstan and India, camel milk is prescribed for early and effective recovery from a variety of disorders. Its vitamin C, iron, unsaturated fatty acids and B-family vitamins boost immunity. Nonetheless, the public awareness of non-cow dairy foods nutritional and health perspectives is highly insufficient. The limited global insight reflects the much
Table 2. Average milk composition per $1 \mathrm{~kg}$ of milk.

\begin{tabular}{lcccc}
\hline Component & Cow & Camel & Yak & Breast \\
\hline Fat, g & 40 & 45 & 65 & 40 \\
Protein, g & 34 & 35 & 51 & 19 \\
Lactose, g & 48 & 44 & 44 & 65 \\
Minerals, g & 7 & 7 & 8 & 2 \\
Solids-non-fat, g & 90 & 86 & 104 & 73 \\
Total solids, g & 133 & 128 & 169 & 121 \\
Cholesterol, mg & 140 & 370 & 220 & 200 \\
Calcium, g & 1.20 & 1.43 & 1.31 & 3.20 \\
Phosphorus, g & 0.93 & 1.16 & 1.06 & 1.4 \\
Saturated FA, g & 24 & 24 & 39 & 18 \\
Monounsaturated FA, g & 11 & 14 & 22 & 16 \\
Polyunsaturated FA, g & 1 & 5 & 4 & 5 \\
\hline
\end{tabular}

$\mathrm{FA}=$ fatty acids.

less available research data and more importantly the less emphasized education, compared to cow dairy foods. Therefore, a primary objective is to delineate exclusive nutritional and technological properties of camel and yak milks in providing healthy foods for humans in the new era. A second primary objective is to help optimize milk science education worldwide with an emphasis on camel and yak dairy foods.

\section{Camel Milk for Nutrition and Health}

Camel milk has on average $11.7 \%$ total solids, $3.0 \%$ protein, $3.6 \%$ fat, $0.8 \%$ ash, $4.4 \%$ lactose, and a $\mathrm{pH}$ of 6.5 . The levels of $\mathrm{Na}, \mathrm{K}, \mathrm{Zn}, \mathrm{Fe}, \mathrm{Cu}, \mathrm{Mn}$, niacin and vita- 
min- $\mathrm{C}$ are greater and that of thiamin, riboflavin, folacin, vitamin B12, pantothenic acid, vitamin-A, lysine and tryptophan are relatively lower compared to cow milk. Milk fat has a molar\% of 26.7 palmitic acid, 25.5 oleic acid, 11.4 myristic acid, and 11.0 palmitoleic acid. Camel milk is more similar to goats' milk and contains less short-chain FA than cow, sheep and buffalo milks. In vitro protein digestibility and protein efficiency ratio values were $81.4 \%$ and $2.69 \%$, respectively, based on $90.0 \%$ and $2.50 \%$ for ANRC-Casein. Camel milk contains substantially less vitamins-A ( 0.10 vs $0.27 \mathrm{mg} / \mathrm{L})$ and B2 (0.57 vs $1.56 \mathrm{mg} / \mathrm{L})$, similar vitamin-E content $(0.56 \mathrm{vs} 0.60 \mathrm{mg} / \mathrm{L})$, and about 3 times greater vitamin-C (37.4 vs $11.0 \mathrm{mg} / \mathrm{L})$ than cow milk, respectively [14].

Camel is known as the gold goal pseudo-ruminant of the 21 st century in arid regions and drylands. In Kazakhstan, $37 \%$ of the total milk is produced by camel, with sheep, yak and cows producing $30 \%, 23 \%$ and $10 \%$, respectively. Camel milk production varies from 3.5 up to $40 \mathrm{~L}$ per day under intensive management. Lactation lasts between 9 - 18 months, with peak yield occurring during the first 2 - 3 months postpartum. In another study, the range of major contents of camel milk were: fat $2.9 \%$ $5.5 \%$, protein $2.5 \%-4.5 \%$, lactose $2.9 \%-5.8 \%$, ash $0.35 \%-0.95 \%$, water $86.3-88.5 \%$ and SNF $8.9 \%$ $14.3 \%$, with a mean specific gravity of 1.03 [15].

The camel milk is receiving more recognition as a global product in optimizing human health. The FAO predicts the camel dairy products will appear on European supermarket shelves. However, logistic challenges in manufacturing and processing must be overcome. Despite the increasing demands from Sahara to Mongolia, the annual 5.4 million tones camel dairy products are greatly inadequate. Sector and local investments must escalate to meet demands and create profitable markets both in the Middle East and the Western world. There are about 300 million potential customers in the Middle East and millions more in Africa, Europe and the Americas for camel dairy products. Although somewhat saltier than cow milk, camel milk represents a cost-effective husbandry under toughest conditions. Camel milk is 3 times richer in vitamin-C than cow milk. In many regions of Iran, Russia, Kazakhstan and India, camel milk has traditionally been prescribed as a food treatment for multiple diseases recovery [16-18]. Oral camel milk administration has proved protective against cadmium induced toxicity in rats [19]. Camel milk is also known for its rich iron, unsaturated fatty acids and B-vitamins.

A main challenge in camel milk processing is its incompatibility with the Ultra High Temperature (UHT) exposure, which is to preserve milk. Also, most camel producers have a nomad nature. An additional challenge is that camels are reputedly stubborn animals. Unlike cows and other docile ruminants storing all their milk in udders, camels store their milk further up the body. Besides all, camel milk production might be considered an inferior-technology business, such that a scanty $5 \mathrm{~L}$ daily secretion is regarded a decent yield. Even under extensive production, improved feeding, husbandry and veterinary services should enable daily yields of up to $40 \mathrm{~L}$. There seems to be at least 17 million camels (Camel us dromedarius) in the world including 12 million in Africa and 5 million in Asia [1]. Milk production varies between 1500 and $15,000 \mathrm{~kg}$ during a lactation of 9 and 18 months [20].

Camel milk has 21 different amino acids [20]. One $\mathrm{kg}$ of camel milk supplies $100 \%$ of daily human requirements for calcium and phosphorus, $57.6 \%$ for potassium, $40 \%$ for iron, copper, zinc and magnesium, and $24 \%$ for sodium [21]. Saturated acids comprise about $61 \%$ of milk FA, including palmitin (27\%), stearin (14.7\%), myristic acid (12.4\%), with kapron and capric acid being only $0.8 \%$ [22]. Thus, camel milk fat is made of $39 \%$ unsaturated FA. Camel milk can help treat some liver problems, lower bilirubin output, lighten vitamin inadequacy and nutrient deficiency, and augment immunity [21]. Fermented camel milk contains some minor amount of alcohol, and $12.4 \%$ of dry matter including $4.8 \%$ fat, $3.6 \%$ protein, $0.12 \mathrm{mg} / \mathrm{kg}$ carotene and $56 \mathrm{mg} / \mathrm{kg}$ vitamin-C. One $\mathrm{kg}$ of fermented milk has $766 \mathrm{kcal}$ energy. From each $3 \mathrm{~L}$ of fermented milk, $1 \mathrm{~kg}$ of curd is produced, almost half of the curd yield in sheep, goat and cow milk. Processing $100 \mathrm{~kg}$ of camel milk in temperatures between $50^{\circ} \mathrm{C}-55^{\circ} \mathrm{C}$ can yield $9-10 \mathrm{~kg}$ of sour cream with $66 \% 6$ of fat. Processing the same amount of camel milk in temperatures between $45^{\circ} \mathrm{C}-55^{\circ} \mathrm{C}$ can generate 12 $14 \mathrm{~kg}$ of sour cream with $35 \%-40 \%$ of fat [23]. One $\mathrm{kg}$ of curds is derived from $6 \mathrm{~L}$ of camel milk, one $\mathrm{kg}$ of dried curd is produced from $9.1 \mathrm{~L}$ of milk, one $\mathrm{kg}$ of melted butter with $98 \%$ of fat is made from $15 \mathrm{~L}$ of milk with $5.66 \%$ of fat, one $\mathrm{kg}$ of sour cream with $76.8 \%$ of fat is made from $13.5 \mathrm{~L}$ of milk with $5.66 \%$ of fat. Fermented camel milk is made of pure starter culture. It must be stirred 5000 - 6000 times by electrical beaters every $3 \mathrm{~h}$. Fermentation starts at temperatures of $20^{\circ} \mathrm{C}$ $25^{\circ} \mathrm{C}$ for the first $24 \mathrm{~h}$. After that it should be cooled down to $18^{\circ} \mathrm{C}-20^{\circ} \mathrm{C}$. Fermentation will be complete after $6 \mathrm{~h}$. The fermented milk can be kept for 60 days in dark bottle at a temperature of $40^{\circ} \mathrm{C}-50^{\circ} \mathrm{C}$ and becomes ready for consumption. Carbonated fermented milk can be preserved up to 90 days.

A major use of camel milk is in allergy caused by various foods, especially ruminant-made foods of mainly cow milk and milk products. Such allergies may cause anaphylactic reactions. These include 1) immediate reaction within 45 min of drinking cow milk that leads to 
urticaria, angioedema and likely true anaphylactic reactions; 2) medium reactions occurring $45 \mathrm{~min}$ to $20 \mathrm{~h}$ that manifests with pallor, vomiting and diarrhea; and 3) long-term reactions happening $>20 \mathrm{~h}$ with mixed reactions in the skin and respiratory and gastrointestinal tracts. Camel is a non-ruminant, despite ruminating, or so called Tylopode. Camel milk is exclusive by its rather low milk fat of about $2 \%$ that is made mainly from polyunsaturated FA. These FA tend to be fully homogenized and form smooth white milk. In addition, camel milk proteins are the most determining constituents in preventing/curing food-born allergies. This is because camel milk lacks $\beta$-lactoglobulin [24] and possesses a different $\beta$-casein (Beg, 1986) than cow milk. These proteins make cow milk allergenic. Moreover, camel milk contains many immunoglobulins, being compatible with human counterparts. Camel milk is also rich in vitamin- $\mathrm{C}$, calcium and iron, thus boosting immune function. Camel milk was recently shown to cure allergies in children of 8-mon to 10-yr old [17].

In several regions of Iran, Pakistan and India, camel milk has long been used therapeutically against dropsy, Jaundice, spleen and liver complexities, tuberculosis, asthma, anemia, and piles [25]. Camel milk is healthier when it is drunk as a cool drink [26]. The milk also apparently has slimming properties [27]. The belief by the Bedouin of the Sinai Peninsula exists that any internal disease can be cured by drinking camel milk through driving from the body all the bacteria. Such milk properties must additionally be attributed to what camel eats. Milk from camel consuming straw might not exhibit the favorable health effects. By the rule of thumb considerations, generally camel milk nutritional value would be considered the lowest following milk from ewe, goat and cow. However, 4 - $5 \mathrm{~kg}$ of camel milk and milk products are sufficient to meet energy, lipids, proteins and calcium requirements of a man.

Following immediate use, the left-over camel milk is curdled and soured. The casein prepared from this milk product is called "industrial casein" [28]. It is not very firm for human intake, and is rather used for glue and gums making. The industrial casein from cow milk is however rich in proteins. The whey proteins of camel milk are richer in nitrogen compared to cow milk [28]. The high proteins and amino acid proportions of camel milk casein make camel milk an appropriate food supplement for humans. The unfavorable odor and taste, however, could affect its popularity. Thus, it is recommended to purify the camel industrial casein to maintain its competitive status in the human health markets.

\section{Yak Milk for Nutrition and Health}

The yak is a bovine subfamily classified as Bos grun- niens. Yak is able to survive in extremely cold and hypo-oxygen environments at as low as $-40^{\circ} \mathrm{C}$ and atmospheric pressure of $550 \mathrm{hPa}$. The estimated total world yak population is approximately 14.2 million [29]. Domestic yaks graze throughout highlands of the Hindu Kush and Karakoram in Afghanistan and Pakistan, the Himalayas in India, Nepal and Bhutan, the Tibetan Plateau and Tian Shan Mountains of Northern China, Western and Northern Mongolia, and also some areas of Russia and other independent states. China has the largest number of yaks in the world with approximately 13 million that comprises $>90 \%$ of all planet yaks [30]. Per lactation yak milk yield of 147 - $487 \mathrm{~kg}$ has been reported [30]. Yak dairy products milk in such high-altitude regions are popular foods. Yak milk has about $16.9 \%-17.7 \%$ solids, $4.9 \%-5.3 \%$ protein, $5.5 \%-7.2 \%$ fat, $4.5 \%-5.0 \%$ lactose, and $0.8 \%-0.9 \%$ minerals. Nepal has initiated to make "yak cheese production" a commercial enterprise. Yak cheese contains $47 \%$ butterfat on a dry matter basis [31,32]. As such, yak milk is often used for making cheese, named as "chhurpi" in Tibetan and Nepali languages, and byaslag in Mongolia. Yak milk butter is used to make "butter tea" that is consumed by Tibetans. It is also used in lamps and made into butter sculptures during religious festivities. Although not widely available in North America, yak dairy products and particularly yak cheese are becoming more accessible in some dairy stores. Yak cheese contains about 4 times more CLA than Canadian cheddar, which shows its potential role in preventing cancer, heart disease, and metabolic disorders such as diabetes. Yak milk is rich in protein, casein and fat compared to cow milk (Table 2). High contents of colloidal and soluble calcium and phosphorus are additional advantages, making yak milk very suitable for cheese making. Milk fat of yak at very high altitudes is richer in PUFA, namely CLA. As such, the resulting cheese and dairy products will have value-added nutraceutical functions.

Yak milk casein has been hydrolyzed to generate antihypertensive peptides, such as YQKFPQY ( $\alpha$ s2-CN; f89-95), LPQNIPPL ( $\beta$-CN; f70-77), SKVLPVPQK $(\beta$ CN; f168-176), LPYPYY ( $\kappa$-CN; f56-61) and FLPYPYY $(\kappa$-CN; f55-61), and two novel ACE-inhibiting peptides $[33,34]$. These peptides are multifunctional bioactives with potential use for producing value-added functional foods and proteins [34]. Compared to cow milk fat, n-3 PUFA in yak milk fat is extremely higher (e.g., 3.2 times) [35]. The n-3 PUFA to n-6 PUFA ratio in yak cheese was 0.87 , but only 0.20 in cow cheese. Based on the minimum healthy set ratio of $>0.25$ [36], yak cheese is considered a highly healthy food for humans. Greater CLA cis-9, trans-11 relative to cow cheese suggests more anticarcinogenic effects of yak cheese and dairy products. 
The amounts of CLA cis-9, trans-11 and CLA trans-11C18:1 in yak cheese have been found to be respectively 4.2 and 4.6 times greater than that in cow cheese [33]. Research data indicate that considerable amount of CLA cis-9, trans-11 originates directly from the rumen. To supply adequate amount of CLA cis-9, trans-11, inclusion of $100 \mathrm{~g}$ yak cheese in daily human diets should suffice [33].

The milk yield of yak and its hybrid, "khainag", is 300 and $470 \mathrm{~kg}$, respectively. The larger diameter of fat globule $(5$ to $6 \mu \mathrm{m})$ eases butter separation in yak milk, thus being suitable for milk cream making. Due to high carotene content, its butter is yellowish and quite delicious. Along with high proteins, yak milk has high acidity. Saturated and unsaturated FA comprise respectively $22 \%$ and $55.2 \%$ of total fat, with greater content of low molecular weight volatile acids, compared to cow milk [37]. Mongolians produce from yak milk butter as well as fermented and protein products. Butter products include milk membrane (orom), and yellow and white butter. The fermented products include yoghurt and koumiss (airag). Wet and dried curds (aaruul) are among protein products. Yak milk has greater contents of total proteins $(4.6 \%-5.8 \%)$, total casein $(4.0 \%)$ and individual caseins than cow milk. The higher $\beta$-casein (45\%) and the lower $\alpha$-s-casein (40\%) along with somewhat higher $\kappa$-casein $(15 \%)$ make yak milk a favorable food for infants as traditionally consumed by Tibetan nomads [37]. Yak milk's whey proteins, $\beta$-lactoglobulin and serum albumin compositions are rather similar to homologous cow whey proteins. Nonetheless, more research is needed to figure out how to optimize yak milk utilization in humans of extreme climatic environments.

China may be the largest producer of naturally fermented yak milk called "kurut". Kurut is an important food for people of Qinghai [38]. Kurut includes products produced by natural fermentation of yak milk in a specially treated big jar for at least $7-8$ days at $10^{\circ} \mathrm{C}-15^{\circ} \mathrm{C}$. These conditions generate enough acid, alcohol and flavor. A common property of kurut is the presence of alcohol and lactic acid. Kurut is almost known in all regions of Qinghai as an indigenous fermented milk product with economic and nutritional importance to the people of Qinghai [39]. Kurut is rich in casein, immunoglobulins, serum albumin, $\beta$-lactoglobulin, $\alpha$-lactalbumin, and two unknown fractions [40,41]. Kurut contains greater numbers of lactic acid bacteria and yeast than other traditional fermented milks (lactic acid bacteria counts of $9.18 \pm 0.851 \log \mathrm{cfu} / \mathrm{ml}$; yeast counts of 8.33 $\pm 0.624 \log \mathrm{cfu} / \mathrm{ml})[40]$.

\section{Conclusions and Implications}

Milk is the most functional natural liquid because it 1) is produced from the most abundant, least digestible nutrients and 2) generously hosts numerous bioactives that function beyond calculated nutritional values. Camel milk contains less short-chain FA than cow, sheep and buffalo milks, and has about 3 times greater vitamin-C than cow milk. One kg camel milk meets $100 \%$ of daily human requirements for calcium and phosphorus, 57.6\% for potassium, $40 \%$ for iron, copper, zinc and magnesium, and $24 \%$ for sodium. Camel milk has long been used to treat liver problems, lower bilirubin output, reduce vitamin inadequacy and nutrient deficiency, and boost immunity. Camel milk reduces food allergies caused by cow milk and milk products. Camel milk has low milk fat content with increased PUFA proportions. Camel milk lacks $\beta$-lactoglobulin and is rich in immunoglobulins, thus being compatible with human milk. Yak milk has greater solids, protein and fat, and is richer in PUFA and casein than cow milk. Yak cheese has about 4 times more CLA than Canadian cheddar. Yak milk casein has been hydrolyzed to produce antihypertensive peptides with multiple bioactive functions and capacities for producing value-added functional foods and proteins. More research is needed to further characterize biophysical and biochemical properties of camel and yak milks as functional substitutes for cow milk and other animal products. Persistent education and data dissemination will be a commitment for such milk natural health implications to be optimally perceived by science and public communities worldwide.

\section{Acknowledgements}

The Ministry of Science, Research and Technology (Tehran, Iran) and University of Zanjan (Iran) are thankfully acknowledged for supporting the author's programs of optimizing science education in the new millennium.

\section{REFERENCES}

[1] FAO, "Food and Agriculture Organization of the United Nations," 2005, FAOSTAT Data. http://faostat.fao.org

[2] A. Nikkhah, "Ruminant Milk and Human Wellbeing: A Multi-species Review," In: Milk Production, Nova Science Publishers, Inc., New York, 2011.

[3] A. Nikkhah, "Science and Pseudo Science of Milk Intake and Human Health," In: Milk Production, Nova Science Publishers, Inc., New York, 2011.

[4] Y. Fukushima, Y. Kawata, T. Onda and M. Kitagawa, "Consumption of Cow Milk and Egg by Lactating Women and the Presence of Beta-Lactoglobulin and Ovalbumin in Breast Milk," American Journal of Clinical Nutrition, Vol. 65, No. 1, 1997, pp. 30-35.

[5] A. Golay, "Cholesterol-Lowering Effect of Skim Milk from Immunized Cows in Hypercholesterolemic Patients," American Journal of Clinical Nutrition, Vol. 52, 
No. 6, 1990, pp. 1014-1019.

[6] K. C. Hayes, A. Pronczuk and D. Perlman, "Vitamin E in Fortified Cow Milk Uniquely Enriches Human Plasma Lipoproteins," American Journal of Clinical Nutrition, Vol. 74, No. 2, 2001, pp. 211-218.

[7] A. L. Lock and D. E. Bauman, "Modifying Milk Fat Composition of Dairy Cows to Enhance Fatty Acids Beneficial to Human Health," Lipids, Vol. 39, No. 12, 2004, pp. 1197-1206. doi.org/10.1007/s11745-004-1348-6

[8] M. A. McGuire and M. K. McGuire, "Conjugated Linoleic Acid (CLA): A Ruminant Fatty Acid with Beneficial Effects on Human Health," Journal of Animal Science, Vol. 77, No. 1, 2000, pp. 1-8.

[9] C. O. Tacket, G. Losonsky, H. Link, Y. Hoang, P. Guesry, H. Hilpert and M. M. Levine, "Protection by Milk Immunoglobulin Concentrate against Oral Challenge with Enterotoxigenic Escherichia coli," New England Journal of Medicine, Vol. 318, No. 19, 1988, pp. 1240-1243. doi.org/10.1056/NEJM198805123181904

[10] M. Pfeuffer and J. Schrezenmeir, "Milk and the Metabolic Syndrome," Obesity Reviews, Vol. 8, No. 2, 2006, pp. 109-118. doi.org/10.1111/j.1467-789X.2006.00265.x

[11] Z. Gao, J. Yin and J. Zhang, "Butyrate Improves Insulin Sensitivity and Increases Energy Expenditure in Mice," Diabetes, Vol. 58, No, 7, 2009, pp. 1509-1517. doi.org/10.2337/db08-1637

[12] P. Tantibhedhyangkul and S. A. Hashim, "Medium-Chain Triglyceride Feeding in Premature Infants: Effects on Fat and Nitrogen Absorption," Pediatrics, Vol. 55, No. 3, 1975, pp. 359-370.

[13] DRI, "Dietary Reference Intakes," Recommended Intakes for Individuals, Food and Nutrition Board, Institute of Medicine, National Academies. National Academy of Sciences, Washington DC, 2007.

[14] Z. Farah, R. Rettenmaier and D. Atkins, "Vitamin Content of Camel Milk," International Journal for Vitamin And Nutrition Research, Vol. 62, No. 1, 1992, pp. 30-33.

[15] B. B. Khan and A. Iqbal, "Production and Composition of Camel Milk: Review," Pakistan Journal of Agricultural Science, Vol. 38, No. 3-4, 2011, pp. 3-4.

[16] M. M. Khan and S. Al-Bukhari, "Translation of the Meanings of the Koran," Al-Medina Islamic University, Saudi Arabia, 1974.

[17] Y. Shabo, R. Barzel, M. Margoulis and R. Yagil, "Camel Milk for Food Allergies in Children," Immunolology \& Allergy, Vol. 7, No. 12, 2005, pp. 796-798.

[18] R. Yagil, "Camels and Camel Milk," FAO (Food and Agricultural Organization of the UN), Rome, 1982.

[19] F. Al-Hashem, M. Dallak, N. Bashir, M. Abbas, R. Elessa, M. Khalil and M. Al-Khateeb, "Camel's Milk Protects against Cadmium Chloride Induced Toxicity in White Albino Rats," American Journal of Pharmacology and Toxicology, Vol. 4, No. 3, 2005, pp. 107-117.

[20] Ch. Tsetsegmaa, D. Altaibayar, P. Dolgorsuren, G. Munh-Erdene and U. Erdenebileg, "Camel Milk Value
Chain Assessment Report," Swiss Agency for Development and Cooperation (SDC), 2008.

[21] Sh. Jadambaa, Ts. Batsuh and P. Baigalmaa, "Research on Use of Camel Milk to Treat Liver Diseases," Product of Technical University, No. 8, 2000, pp. 17-21.

[22] R. Indra, A. Magash and N. Biichee, "Camel Research," Paper 303, Ulaanbaatar, Mongolia, 1998.

[23] R. Indra and Osorhaan, "Industrial Processing of Camel Milk," Agricultural Magazine, No. 1, Ulaanbaatar, 1987, pp. 303-304.

[24] U. Merin, S. D. Bernstein, N. Bloch-Damti, R. Yagil, C. van Creveld and P. A. Lindner, "Comparative Study of Milk Proteins in Camel (Camelus dromedarius) and Bovine Colostrums," Livestock Production Science, Vol. 67, No. 3, 2001, pp. 297-301. doi.org/10.1016/S0301-6226(00)00198-6

[25] A. A. Akhundov, B. Dyrdyev and E. R. Serebryakov, "Effect of Combined Treatment on Water Electrolyte Exchange in Pulmonary TBC Patients," Zdravookhr Turkm, Vol. 16, 1972, pp. 40-44.

[26] S. A. Yasin and A. Wahid, "Pakistan Camels. A Preliminary Survey," Pakistan Agriculture, Vol. 8, No. 3, 1957, pp. 289-297.

[27] R. Pant and P. Chandra, "Composition of Cow and Camel Milk Proteins and Industrial Casein," Milchwissenschaft, Vol. 35, No. 2, 1980, pp. 91-93.

[28] F. N. Talpur, N. N. Memon and M. L. Bhanger, "Comparison of Fatty Acid and Cholesterol Content of Pakistani Water Buffalo Breeds," Pakistan Journal of Analytical and Environmental Chemistry, Vol. 8, No. 1-2, 2007, pp. 15-20.

[29] G. H. Wiener, H. Jianlin and L. Ruijun, "Origins, Domestication and Distribution of Yak," The Yak, 2nd Edition, RAP Publication; FAO (Food and Agricultural Organization of the United Nations) Regional Office for Asia and the Pacific, Bangkok, 2003, pp. 1-16.

[30] S. Dong, R. Long and M. Kang, "Milking Performance of China Yak (Bos grunniens): A Preliminary Report," African Journal of Agricultural Research, Vol. 2, No. 3, 2007, pp. 52-57.

[31] D. B. Mondal and R. N. Pal, "Yak Milkschemical Constituents," Indian Journal of Dairy Science, Vol. 46, No. 4, 1996, pp. 413-414.

[32] D. Neupaney, J. Kim, M. Ishioroshi and K. Samejima, "Study on Composition of Nepalese Cheeses, Yak Milk, and Yak Cheese Whey," Milk Science, Vol. 46, No. 2, 1997, pp. 95-102.

[33] J. Jiang, S. Chen, F. Ren, Z. Luo and S. S. Zeng, "Yak Milk Casein as a Functional Ingredient: Preparation and Identification of Angiotensin-I-Converting Enzyme Inhibitory Peptides," Journal of Dairy Research, Vol. 74, No. 1, 2007, pp. 18-25. doi.org/10.1017/S0022029906002056

[34] X.-Y. Mao, J.-R. Nib, W.-L. Sunb, P.-P. Haob and L. Fan, "Value-Added Utilization of Yak Milk Casein for the Production of Angiotensin-I-Converting Enzyme Inhib- 
itory Peptides," Food Chemistry, Vol. 103, No. 4, 2007, pp. 1282-1287. doi.org/10.1016/j.foodchem.2006.10.041

[35] M. M. Or-Rashid, N. E. Odongo, B. Subedi, P. Karki and B. W. McBride, "Fatty Acid Composition of Yak (Bos grunniens) Cheese Including Conjugated Linoleic Acid and Trans-18:1 Fatty Acids," Journal of Agricultural and Food Chemistry, Vol. 56, No. 5, 2008, pp. 1654-1660. doi.org/10.1021/jf0725225

[36] A. P. Simopoulos, "The Importance of the Ratio of Omega-6/Omega-3 Essential Fatty Acids," Biomedical Pharmacotherapy, Vol. 56, No. 8, 2002, pp. 365-579. doi.org/10.1016/S0753-3322(02)00253-6

[37] H. Li, Y. Ma, A. Dong, J. Wang, Q. Li, S. He and J.-L. Maubois, "Protein Composition of Yak Milk," Dairy Science and Technology, Vol. 90, No. 1, 2010, pp. 111-117. doi.org/10.1051/dst/2009048

[38] P. Cheng, "Livestock Breeds of China: Animal Produc- tion and Health" Paper 46 (E, F, S), FAO, Rome, 1984.

[39] Y. Cao, W. Gan, Z. Ye, H. Yu, B. Huang, Y. Jiang, et al., "Investigation on Yak Milk Products and Their Traditional Process Craft of Daocheng Country," Proceedings of 4th International Congress on Yak, Research Institute of Animal Science and Veterinary Medicine of Ganzi Prefecture, 2004, pp. 4-67.

[40] H. Zhang, J. Xu, M. Wang, T. Sun, H. Li and M. Guo, “A Survey on Chemical and Microbiological Composition of Kurut, Naturally Fermented Yak Milk from Qinghai in China," Food Control, Vol. 19, No. 6, 2008, pp. 578-586. doi.org/10.1016/j.foodcont.2007.06.010

[41] X. X. Zhao, "Milk Production of Chinese Bactrian camel (Camelus bactrianus). Milk production of Chinese Bactrian Camel (Camelus bactrianus)," Proceedings of the Workshop on Dromedaries and Camels, Milking Animals, Nouakchott, 24-26 October 1994, pp. 101-105. 